\author{
V International Forum on Teacher Education
}

\title{
Factors of Students' Successful Learning and Cognitive Activity at the English Lessons
}

\author{
Marina. S. Ilina * \\ Kazan Federal University, Elabuga, Russia
}

\begin{abstract}
The article deals with the factors of students' successful learning and cognitive activity at the English lessons which is regarded as a significant aspect of teaching and learning. The hypothesis of the study is the efficiency of teaching the English language. That is based on the unity of the following pedagogical aspects: motivation as the main factor of learning the English language and the importance of communicative culture development at the English lessons. The purpose and hypothesis define the following research tasks: to analyze motivational aspect as one of the successful factors to teach English and to find the best conditions of students' communicative culture formation. The main research methods are theoretical and methodological analysis of scientific, philosophical, psychological, pedagogical, educational and methodical literature on the topic of research; analysis, comparison and generalization of University teachers' experience; analysis and systematization of University students' educational results (creative works, etc.); pedagogical experiment; observation; interviews; questionnaires; a modeling; a method of expert evaluation. Thus, the research result helps to improve students' successful learning and cognitive activity at the English lessons. Thus, practical significance of the research is in developing a differentiated system based on situational communicative tasks aimed at students' successful learning and cognitive activity at the English lessons.
\end{abstract}

Keywords: English language, communicative skills, motivation, cognitive interest, academic activity, students.

(C) 2019 Marina. S. Ilina.

This is an open access article distributed under the terms of the Creative Commons Attribution License (CC BY 4.0), which permits unrestricted use, distribution, and reproduction in any medium, provided the original author and source are credited.

Published by Kazan Federal University and peer-reviewed under responsibility of IFTE-2019 (V International Forum on Teacher Education)

\section{Introduction}

Modern trends of intercultural integration, one aspect being continuity of communicative skills 
forming and encouraging teachers of English to search new techniques to create factors of students' successful learning and cognitive activity at the English lessons. In the Concept of Russian educational modernization (CREM, 2010) the continuity of communicative culture formation is stated to be important in continuous educational system. It is based on motivational aspect and communicative skills development of each member of the society.

In this regard one of the most important aims of teaching a foreign language is to prepare learners with a high level of communicative culture to be ready for cultural, professional and personal communication.

\section{Problem Statement}

The need to find factors of students' successful learning and cognitive activity at the English lessons is not fully realized and is not unveiled in the pedagogical theory. Psycho - pedagogical maintenance of the process does not correspond with modern tendencies in education. Pedagogical requirements of its realization are not worked out.

The analysis of literature on the research problem helps to identify the main factors of students' successful learning and cognitive activity based on communicative culture at English lessons.

Students' successful learning and cognitive activity depends on creation of right motivation and communicative culture development at the English lessons. Basic skills of communicative culture are started to be formed at secondary school. Professional orientation takes place at vocational schools and universities. The connection of different subjects with practice play very important role in communicative culture formation.

\section{Research Questions}

The problem of communicative culture formation is one of the actual issues of modern society's development. Zimnyaya (1985) defines communication as a form of social - communicative activity where a "verbal intercourse" is a specific human interaction in society community.

Indeed, a communicative culture is an integrative person's quality, adequately regulating its sociocultural and professional status. It determines professional growth and proper verbal interaction in everyday and professional situations.

It is not surprising that this assessment agenda with its published data, its targets based on national test results and teacher's assessment may depend on many internal and external factors.

\section{Research Methods}

The main methods of investigation are as follows:

- theoretic - methodological analysis of scientific, philosophic, psycho - pedagogical, educational literature on research topic; analysis, comparison and generalization of teachers' experience at universities;

- Analysis and results systematization of students' activities (creative work), pedagogical experiment, observation, conversation, survey, modeling, method of expert evaluations, method of mathematical statistics.

Reliability and validity of research results are ensured by reference to fundamental work on the issue by unity of empirical and theoretical methods corresponding with its subject matter, aims and objectives. It is also assured by complex character of pedagogical experiment using mathematical methods 
to get data experimentally and by sufficient representative excerpts with the authors' participation in experimental work.

\section{Findings}

Scientists consider that students' successful learning and cognitive activity is an important aspect of both secondary and professional schools and University at the English lessons. It requires certain requirements and techniques aimed at achieving good results at the English language lessons.

The most important aspect of modern educational paradigm is the realization of continuity principle during teaching English. Other principles are situational approach, individualization, professionalization, stage differentiation, level determinationand cross-cultural integration.

Students' successful learning and cognitive activity may be based on the integration of foreign language elements, communicative situations and authentic texts differentiating different learners' levels in teaching the English language. The procedural components are characterized by differentiation of goals, forms and methods of teaching in accordance with the stages of communicative culture formation.

In the process of foreign language learning communicative system enables to organize teaching in the dialogue of cultures that reveals the forms of communicative interaction in interpersonal and professional relations.

The problem in recent years is that teaching English has been more technical than professional, focused on the short-term implementation of Government priorities. In particular, the current policy context of assessment seems to be one when Broadfoot $(1999$, p. 5) quotes "assessment is a "neutral" measuring instrument which only requires further technical developments to make it more effective". The lack of support for resources to support teachers in their interpretation of level descriptions and their application of teacher assessment is not surprising in such a climate since the assumption is the solution is technical and not about professional learning and teacher collaboration" (Broadfoot, 1999, p. 13).

Students' learning and cognitive activity is carried out according to the following two factors:

1) content and logic familiarization of educational subject "Foreign language";

2) knowledge conformities developing teaching process.

The first factor determines continuity of academic subject construction. The basic contents of academic subjects, is realized in a sequence providing educational issue, in accordance with the stages of communicative culture formation at the English language lessons in the system 'school - vocational school - university". The second factor shows the conformities to educational continuous process. It requires didactic requirements at the English lessons.

It is based on level situational communicative tasks and authentic assignments corresponding to the educational standards and meeting the requirements of forming communicative culture formation at the English lessons.

Implementation of teaching principles regulates learners' successful learning and cognitive activity at every stage of educational process teaching the English language. It is the means of setting the link between learning and practice with its aims at a person's professional development.

The process of students' learning and cognitive activity during foreign language teaching has its own characteristics at each stage of development. Quantitative changes are transformed into qualitative indicators during developing from the previous level of teaching to the next one.

At school the purpose was to start learners' learning and cognitive activity and to help them to be ready to develop skills at higher level. 
At vocational schools a complex of methods and different techniques was used to form learners' communicative culture (communicative situations, project assignments, level authentic texts, etc.). The tasks are simple and primitive at the English language lessons.

At university didactic materials were introduced aimed at the realization of communicative situations of higher level. Thus, at a secondary school communicative culture formation was identified as a stage forming the basic level of communicative skills and then developed at vocational school and university.

Consequently, it is important to define the factors of students' learning and cognitive activity and to develop communicative skills at the English lessons.

It shows that the use of authentic - problematic situations affect the efficiency of educational process at each stage of foreign language learning in the system " school - vocational school - university." The members of communication solve real and communicative tasks of future professional activity. These tasks are of problematic nature and stimulate an independent search for their solutions.

The principle of continuity performs a methodological function in relation to specific techniques of communicative culture formation. The issue of general concept "continuity of the communicative culture formation" in the system " school - vocational school - university " includes more restrictive requirements (continuity of profiling, continuity of educational levels, etc.), which constitute structural components of communicative culture formation and perform a regulatory function.

Continuity of communicative culture formation at the English lessons is based on a model of communicative culture formation consisting of targets, principles, and communicative techniques of the English language teaching. The process of foreign language teaching is based on integration of the main foreign language teaching techniques: communicative technique (Passov, 1989), the technique "Dialogue of Cultures" (Bibler, 2009) and collaborative learning technique (Polat, 2000), providing successive communicative culture formation.

During English lessons the following aspects are taken into account: matching the content structure of foreign language teaching to the logic of continuity communicative culture formation at the English lessons, professionalization, specialization, pedagogical principles, the prospects of communicative culture formation in the process of foreign language teaching, based on level system of communicative tasks and authentic texts.

A set of educational techniques based on continuity principle and relevant objectives of the study has been developed. The experimental results have shown that the influence of individual pedagogical techniques varies depending on the goals and objectives of each stage of communicative culture formation at the English lessons.

\section{Conclusion}

Foreign language teaching is characterized by educational information, forms, methods, objectives, communicative activity and motives of learning the English language.

Thus, practical significance of the research is in developing a differentiated system based on situational communicative tasks aimed at students' successful learning and cognitive activity at the English lessons. 


\section{References}

Bibler, V. S. (2009). The foundations of the School of the Dialogue of Cultures Program. Journal of Russian \& East European Psychology, 47(1), 34-60.

Black, P., \& Wiliam, D. (1998). Assessment and classroom learning. Assessment in Education: principles, policy \& practice, 5(1), 7-74.

Broadfoot, P. (1999). Empowerment or performativity? English assessment policy in the late twentieth century. Paper presented at the British Educational Research Association Conference, 9, Brighton.

Concept of Russian educational modernization for the period up to 2010. (CREM). (2010). Public education. Retrieved from http://www.edu.ru/documents/view/1660/

Kagan, M. C. (1996). Philosophy of culture. Saint-Petersburg: Metropolis.

Passov, E. I. (1989). The basics of communicative foreign communication methodic. Moscow: Mysl.

Polat, E. S. (2000). Obuchenije v sotrudnichestve. Inostrannue jazuki v shkole, 1, 4-7.

Zimnyaya, I. A. (1985). Verbalnoe Myshlenie (psikhologicheskii aspect) [Verbal reasoning (psychological aspect)]. Moscow, Nauka. 